DOI https://doi.org/10.30525/978-9934-26-075-9-17

\title{
РОЛЬ СУДИННОГО ФАКТОРА В ПРОГРЕСУВАННІ ХВОРОБИ ПАРКІНСОНА
}

\author{
Лукашевич П. В. \\ кандидат медичних наук, \\ лікар відділення нейрореабілітаиії \\ ДУ «Інститут нейрохірургії імені академіка А. П. Ромоданова \\ Національної академії медичних наук Украӥни»

\section{Степаненко I. B.} \\ доктор медичних наук, старший науковий співробітник, \\ завідувачка відділення нейрореабілітації \\ ДУ «Інститут нейрохірургії імені академіка А. П. Ромоданова \\ Національної академії медичних наук України» \\ Лихачова Т. А. \\ лікар відділення нейрореабілітаиії \\ ДУ «Інститут нейрохірургії імені академіка А. П. Ромоданова \\ Начіональної академії медичних наук Украӥни» \\ Попова І. Ю. \\ кандидат медичних наук, \\ лікар відділення нейрореабілітаиії \\ ДУ «Інститут нейрохірургії імені академіка А. П. Ромоданова \\ Наиіональної академії медичних наук Украӥни» \\ м. Київ, Украӥна
}

Хвороба Паркінсона (ХП) - хронічне прогресуюче нейродегенеративне захворювання центральної нервової системи, головними клінічними проявами якого $є$ порушення рухової сфери у вигляді гіпокінезії, ригідності та тремтіння, й ряду немоторних проявів - вегетативних порушень, депресії, когнітивних змін. При загальній розповсюдженості $0,3 \%$ в світі вона зростає до $1 \%$ в групі старше 60 років и до $4 \%$ після 75 [1]. За даними міжнародної асоціації «Робоча група по хворобі Паркінсона» найближчим часом спостерігатиметься тенденція до помолодшання ХП. Вже сьогодні кожен десятий пацієнт має вік до 50 років і кожен двадцятий - до 40 років [2].

Етіологія ХП до кінця не з'ясована, більшість дослідників дотримується точки зору поліетіологічного генезу ХП. Комплексний вплив спадкових факторів, зовнішнього середовища, старіння розглядається як найбільш вірогідний варіант причини виникнення ХП. 5-15\% 68 
пацієнтів з ХП мають обтяжений сімейний анамнез, однак у більшості тип успадкування не з'ясований. Клінічна симптоматика хвороби маніфестує при втраті більше 80\% клітин компактної частини чорної субстанції, хоча характерним для ХП вважається наявність в клітинах чорної субстанції тілець Леві, знайдених також в клітинах кори, ядрах блукаючого нерва, блакитної плями. У людей похилого віку без клініки паркінсонізму тільця Леві виявляються в 16\% випадків. В ряді випадків клініка ХП виникає при токсичному впливі 1-метил-4-феніл-1,2, 3,6-тетрагідропіридин (МФТП), судинному або інфекційному ураженні головного мозку - в таких випадках прийнято говорити про вторинний паркінсонізм. При початку захворювання в більш похилому віці ХП прогресує швидше, частіше супроводжується деменцією, а в уражених клітинах знаходять більший вміст тілець Леві [3].

При патологоанатомічному дослідженні судин головного мозку в капілярах пацієнтів було виявлено стоншення базальної мембрани, дегенерація періцитів, відкладення колагену, ураження ендотеліальних клітин, схожі з такими ж при хворобі Альцгеймера [4]. Просвіт внутрішніх сонних артерій розширений, стінка нерівномірно потовщена за рахунок інтими, м'язова оболонка склерозована і місцями стоншена, внутрішня еластична мембрана збережена лише місцями, інтима різко потовщена за рахунок рихлої колагенової тканини. Подібні зміни спостерігались і в інших судинах. Периваскулярні порожнини, так звані криблюри, були знайдені в області підкіркових гангліїв, в білій речовині окремих звивин лобних долей, а іноді і в потиличних. Вени різко розтягнуті, стінка стоншена. При електронній мікроскопії мікроциркуляторного русла ендотеліоцити були дистрофічно змінені, 3 електронно прозорою цитоплазмою, розпадом органел, періцити 3 ліпідоподібними включеннями в цитоплазмі і ліпофусциновими гранулами на стадії їх формування. За наявності включень періцити нагадували макрофаги.

Ураження судин головного мозку 3 розвитком їх атонії може призводити до хронічної ішемї чи до повторних порушень мозкового кровообігу, внаслідок чого формуються лакунарні інфаркти і зміни по типу лейкоареозу, що були знайдені у третини хворих з діагнозом ХП [5]. Найбільш суттєво вражений м'язовий шар, внаслідок чого на достатньо прямих відділах дрібних артерій були виявлені аневризми, що можливо є наслідком недосконалої вегетативної іннервації чи токсичного впливу гіпергомоцистеїнурії [6]. Вегетативні порушення є облігатними при ХП, але у різних пацієнтів в різній мірі страждають різні ланки вегетативної нервової системи. Ортостатична гіпотензія може бути побічним ефектом від лікування леводопою, чи наслідком вегетативної денервації судинної системи. Вона розвивається на пізніх стадіях ХП. На відміну від ортостатичної гіпотензії при мультисистемній атрофії, при ХП більше уражена постгангліонарна інервація серцевого м'яза [7]. 
Вегетативна іннервація судин головного мозку при ХП раніше не досліджувалася. Враховуючи вищевказані зміни церебральних судин й високу розповсюдженість ортостатичної гіпотензії у пацієнтів з ХП ймовірним представляється також порушення церебральної гемодинаміки, що підтверджує актуальність теми та доцільність вивчення показників гемодинаміки при ХП.

Мета роботи - виявити клініко-фізіологічні особливості функціонального стану іннервації судин головного мозку у хворих на ХП середнього та похилого віку, визначити взаємозв'язок між ступенем порушення іннервації судинного русла головного мозку і швидкістю прогресування хвороби, з'ясувати розповсюдженість порушення іннервації судинного русла головного мозку у випадку супутньої ортостатичної гіпотензії і без неї.

Під нашим спостереженням знаходилось 25 хворих з діагнозом ХП, $10 з$ яких мали супутню ортостатичну гіпотензію. Обстеження хворих включало: ретельний збір скарг та анамнезу захворювання і життя, дані медичної документації, детальне клініко-неврологічне обстеження, проведення ортокліностатичної проби за методикою W.Birkmayer, проведення допплерографії судин голови та шиї з використанням ортостатичних проб. Вивчення змін показників при проведенні ортостатичної проби 3 використанням транскраніальної допплерогафії є одним 3 найбільш адекватних методів вивчення нейрогенної регуляції церебрального кровотоку [6]. Нормальними показниками при проведенні ортостатичних проб вважається підвищення лінійної швидкості кровотоку (ЛШК) по інракраніальних судинах. При зменшенні ЛШК до 10\% від вихідних показників регуляція мозкового кровотоку оцінюється, як відносно компенсована, при зменшенні більше ніж 10\% - некомпенсована [8]. Визначення стадії і важкості захворювання проводилось за міжнародною шкалою UPDRS [1]. Підставою для оцінки швидкості прогресування ХП слугував введений умовний коефіцієнт прогресування, який вираховувався, як відношення балів за шкалою UPDRS до кількості місяців захворювання. Швидкий тип прогресування встановлювався при показниках цього умовного коефіцієнта більше 2,5, повільний - до 2,5.

Клінічно у всіх пацієнтів відмічалось тремтіння кінцівок, підвищення м'язового тонусу, акінезія. Вегетативні розлади (гіперсалівація, запори, порушення сечовипускання) в цілому по групі спостерігались у 18 пацієнтів (72\%), а серед хворих з ортостатичною гіпотензією, що супроводжувалась запамороченням при різкому вставанні, вегетативні розлади спостерігались у всіх 10 пацієнтів (100\%). Тривалість захворювання в цій групі хворих була більше 5 років. При дослідженні стану мозкової ауторегуляції виявлялись ознаки іiї порушення у більшості пацієнтів з ХП - у 22 пацієнтів з усіх обстежених хворих (88\%) ЛШК зменшувалась до $10 \%$ від вихідного рівня. Однак суттєво порушення 70 
ауторегуляції було виражене в групі пацієнтів з ортостатичною гіпотензією, в яких зменшення ЛШК було більшим, ніж 10\% від вихідного рівня при зміні положення тіла. У трьох пацієнтів, тривалість захворювання яких становила до одного року (15\%), спостерігалася нормальна реакція, тобто збільшення ЛШК при зміні положення тіла, що супроводжувалось і підвищенням АТ. Крім того, було встановлено, що у всіх хворих $з$ супутньою ортостатичною гіпотензією коефіцієнт швидкості прогресування був більшим, ніж 2,5, тобто швидкість прогресування захворювання в цій групі хворих була більшою.

Висновки: Порушення іннервації судин головного мозку, яке спостерігається у більшості пацієнтів з ХП, є важливим фактором прискорення прогресування захворювання. Таке порушення іннервації виявлене у більшості пацієнтів з ХП (88\%), однак особливо - у пацієнтів 3 супутньою ортостатичною гіпотензією $(100 \%)$, що супроводжується і прискоренням швидкості прогресування захворювання. Воно, вірогідно, $\epsilon$ наслідком неадекватності кровопостачання, що потребує подальшого вивчення причин порушення церебральної гемодинаміки і можливих методів її корекції.

\section{Література:}

1. Глозман Ж.М., Левин О.С. Экстрапирамидные расстройства: руководство по диагностике и лечению. М.: МЕДпресс-информ, 2002. С. $74-86$.

2. Иллариошкин С.Н. Современные представления об этиологии болезни Паркинсона. Неврологический журнал. 2015, 20, С. 4-13.

3. Hallyday G.M., McCann H. The progression of pathology in Parkinson's disease. Ann N Y Acad Sci. 2010. Jan, P. 1184.

4. Farkas E., De Jong G., de Vos R. et al. Pathological features of cerebral cortical capillaries are doubled in Alzheimer's disease and Parkinson's disease. Acta Neuropathol. 2000. V. 100, P. 395-402

5. Шток В.Н., Левин О.Г., Федорова Н.В., Экстрапирамидные расстройства. М., 2002. 128 с.

6. Шахнович А.Р., Шахнович В.А. Диагностика нарушений мозгового кровотока. Транскраниальная допплерография. М., 1997. 325 с.

7. Goldstein D.S., Holmes C.S., Dendy R., Bruse S.R., Li ST Ortostatic hypotention from sympathetic denervation in Parkinson's disease. Neurology. 2002. Apr, P. 58.

8. Leliuk V.G., Leliuk S.E. Diagnostic possibility of duplex scanning for the evaluation of patients with Parkinson disease. Cerebrovasc. Dis. 1999. V. 9, P. 22. 